\title{
Enhancing The Added Value of Akar Kelape Snack: An Effort to Improve Marketing Performance
}

\author{
Agus Cholik ${ }^{1}$, Resista Vikaliana ${ }^{2}$ \\ \{ mascholikaja@gmail.com $^{1}, \underline{\text { resista@stiami.ac.id }}{ }^{2}$ \}
} Fakultas Ilmu Sosial dan Manajemen, Institut Ilmu Sosial dan Manajemen Stiami, Jakarta,
Indonesia

\begin{abstract}
The purpose of this research is to generally aim at realizing culinary delights that are intended to be a typical Betawi culinary tourism destination, which is to make a standard recipe for Akar Kelape and to make Root Kelape products have high selling value. This research was conducted with qualitative approach. The presentation of Akar Kelape from the standard recipe which is the result of this research, can be used as a guide for culinary preservation, especially traditional Betawi cuisine. In this study, based on observations, the brand given to the predetermined standard recipe was Akar Kelape "Nyak Babe", a Betawi Typical Snack with the tagline "Right Treats at the Right Time". To further increase the selling value, a design for the Akar Kelape product packaging has been produced
\end{abstract}

Keywords: Akar Kelape, Standard Recipe, Marketing Performance.

\section{Introduction}

Jakarta, as the capital city of Indonesia, is a tourist destination visited by both domestic and foreign tourists. Apart from being the country's gateway to other tourist destinations, these tourists have made Jakarta their main destination. Indonesian Central Statistics Agency/ BPS Data for DKI Jakarta Province as of August 2018, reported the number of foreign tourist visits. Cumulatively (January-August 2018), the number of foreign tourist visits to Indonesia reached 10.58 million visits, an increase of 12.30 percent compared to the number of foreign tourist visits in the same period in 2017 which totaled 9.42 million visits. This increase shows good opportunities in the tourism sector.

To further increase the number of tourist visits, the Government established culinary tourism destinations, which previously did not exist. This is based on what tourists are looking for the first time when visiting a destination is culinary [1]. Traditional Indonesian culinary delights are one of the most delicious in the world with complete spices. Within one province it consists of very diverse ethnic cuisines. In DKI Jakarta Province, the Betawi ethnic group is one of the ethnic groups who has several culinary riches. The existence of Betawi culinary, like other ethnic groups in Indonesia, accompanies the dynamics of people's lives, such as ceremonies and celebrations (Pridia, 2016).

Traveling is of course related to culinary activities or food and drink. In addition, the activity of buying souvenirs as souvenirs or souvenirs to take home. From monitoring via the internet, the following three places were obtained as souvenir centers for Jakarta 1. Jakarta Typical Souvenirs Center is located in Central Jakarta 
2. Romlah Souvenirs Jakarta is located in South Jakarta

3. The Mpok Nini Warung. The Betawi Souvenir Center is located in Bekasi City

By looking at the number of tourists and the position that is only scattered in Central Jakarta, South Jakarta and Bekasi City, it is not easy to buy souvenirs for tourists. To maintain or preserve traditional Betawi culinary delights, an effort is needed to introduce it more widely to the community.

Betawi culinary souvenirs that are sold in Jakarta, including Roti Buaya, Kacang Ketapang, Dodol Betawi, Beer Pletok. There is a culinary that has the potential to be developed as a typical Jakarta souvenir, namely Kelape Root Cake. Therefore, in this study a standard recipe for Kelape Root was prepared and made packaging and other marketing elements so that the Kelape Root could become a typical Betawi souvenir product with high selling value.

The purpose of this research is to generally aim at realizing culinary delights that are intended to be a typical Betawi culinary tourism destination, which is to make a standard recipe for Akar Kelape and to make Root Kelape products have high selling value.

\subsection{Intangible Cultural Heritage}

Intangible Cultural Heritage based on the UNESCO Convention for The Safeguarding of The Intangible Cultural Heritage 2003: Intangible Cultural Heritage is a variety of practices, representations, expressions, knowledge, skills - as well as instruments, objects, artifacts and cultural spaces related to them - that society, groups and, in some cases, the individual is part of the cultural heritage. This intangible cultural heritage is passed down from generation to generation, being continuously recreated by communities and groups in response to their surrounding environment, their interaction with nature and their history, and providing a sustainable sense of identity, to appreciate cultural differences and human creativity.

Intangible Cultural Heritage is manifested in the following areas:

Traditions and Oral Expressions, including language as a vehicle for intangible cultural heritage.

1. Performing Arts

2. Indigenous peoples' customs, rites and celebrations;

3. Knowledge and behavioral habits about the universe;

4. Traditional skills.

5. Traditions and oral expressions such as language, ukno script, traditional games, rhymes, folk tales, mantras, prayers, folk songs and others.

6. Performing arts include dance, sound arts, music, theater, film and others.

7. The customs of the traditional community, rituals, and celebrations, for example, traditional ceremonies (life cycle ceremonies), social organization systems, traditional economic sisters and others.

8. Knowledge and behavioral habits about the universe, for example traditional knowledge, local wisdom, traditional blocking and others

Traditional skills and skills such as traditional technology, traditional architecture, traditional clothing, traditional accessories, traditional crafts, traditional culinary, traditional transportation media, traditional weapons and so on..

Indonesia's Intangible Cultural Heritage to be selected for proposal in UNESCO's ICH list must meet the following criteria:

1. A cultural identified of one or more Cultural Communities; 
2. Cultural values that can increase awareness of identity (pengampu culture and society of Indonesia) and national unity

3. Having the uniqueness / uniqueness / rarity of an ethnic group that strengthens the identity of the Indonesian nation and is part of the community

4. A living tradition and memory collective relating to the preservation of nature, the environment, and is useful for humans and life;

5. Intangible Cultural Heritage has a socio-economic and cultural impact (multiplier effect);

6. Urge to be preserved (cultural elements / works and actors) due to natural events, natural disasters, social crises, (cultural crises,) political crises, and economic crises;

7. Become a means (and guarantor) for sustainable development; become a guarantor for sustainable development

8. The proposed cultural work must be representative of the province (the proposed type may consist of several similar cultural works scattered in areas within the province)

9. Do not submit cultural works that are extinct or no longer have supporting communities

10. Intangible Cultural Heritage whose existence is threatened with extinction

11. Intangible Cultural Heritage is prioritized in border areas with other countries;

12. Vulnerable to Intangible Cultural Heritage claims by other countries.

13. It has been passed down from more than one generation

14. Owned as wide as a certain community

15. No conflict with human rights and conventions in the world (laws and regulations in Indonesia)

16. Supporting cultural diversity and the natural environment

\subsection{Preservation of Traditional Culinary Tourism}

The definition of preservation, in the Big Indonesian Dictionary (KBBI), it is stated that it comes from the root word 'sustainable', which means that it remains unchanged forever. Then, in the rules of using Indonesian, the prefix and suffix have the meaning to describe a process or effort (verb). Thus, preservation can be interpreted as an effort or process to make something remain forever and unchanged. Can also be defined as an effort to maintain something in order to always remain as it is.

Local cuisine or local cuisine reflects the history and culture of an area and can be an attraction for tourists. Apart from providing good quality food for tourists, efforts should be made to promote the unique dishes of the destination which are favored by tourists, at least trying local cuisine (Inskeep, 1991). Each culture has its own peculiarities in eating activities, from preparing food ingredients, cooking, packaging, to eating. Given the importance of cultural values, the preservation of traditional culinary delights must always be pursued. It also needs to be passed on to the younger generation as cultural stakeholders. Sustainability cannot stand alone, because it is always coupled with development, in this case survival. Sustainability is an aspect of stabilizing human life, while survival is a reflection of dynamics. (Soekanto, 2003)

Winarno (1993) argues that traditional food is food that is thick with local traditions. Meanwhile, Hadisantosa (1993) defines traditional food as food consumed by specific ethnic groups and regions, processed based on recipes passed down from generation to generation. The materials used come from the local area and the food produced is also in accordance with the tastes of the community.

Culinary culture has been an area that has been neglected until recently[2]. However, culinary culture has always been an enduring part of culture and tradition. To put it in a different way, a cuisine in which the many different identities of a society are joined together 
and national feelings are felt the most are a reflection of daily lifestyle, religious beliefs, customs, traditions and customs. So it can be understood that food is closely related to culture. Everyone will never forget the traditional food. Although the process of globalization and economic development is the cause of the shift in diet, people will always produce and seek traditional food to meet their daily food needs. This phenomenon is the basis for culinary business actors to serve a variety of traditional foods in big cities [3]. Because, they believe that people who migrate to the city will tend to look for traditional food in the area.

One of the best known cookies is Akar Kelape. Akar Kelape Snack is a cookie from Betawi and its surroundings. This cake is generally served with fried peanuts and rengginang during special events, such as during Eid or celebration. Despite the name, coconut root cake, this cake is not made from coconut root. The name "Akar Kelape or Coconut Root" is taken from its shape which is similar to coconut root. Even so, there is a part of the coconut that is used in the manufacture of this Akar Kelape Snack, namely the part of the flesh that has been processed into coconut milk.

\section{Method}

The preparation of this study used a qualitative research approach, using purposive sampling technique. Purposive sampling is the deliberate withdrawal or sampling of research informants, namely the determination of informants with certain conditions. In this study, the requirements for informants taken were experts or experts who had in-depth knowledge of traditional Betawi culinary delights. The key informants in this research were Anisa Sitawati and Cucu Sulaicha. Other informants were Suzen HR Tobing, Yahya Andi Saputra and Heryus Saputra. Data collection was carried out through focus group discussions/ Focus Group Discussion -FGD and in-depth interviews and observations. The research data were analyzed using Grounded Theory. The stages of this research were carefully designed so that they met the criteria of the scientific method. The criteria referred to are the existence of significance, conformity between theory and observation, can be generalized, can be reexamined, the existence of accuracy and accuracy, and can be proven.

\section{Result and Discussions}

\subsection{Culinary History}

The origin of the coconut root cake is unknown. Akar Kelapes seem to have to decorate the table, side by side with rangginang and fried peanuts onions, when Eid arrives. The founder of the Bekasi Community Kinship Board (BKMB) Bhagasasi, an organization for the gathering of Bekasi people, said that after onion fried peanuts, Akar Kelape is a must-have cookie.

\subsection{Culinary Description}

As an intangible inheritance, it is not only culinary but also in the form of expression and is considered to be endangered, so as a category of intangible inheritance, it must be the result of practice which is improved from time to time. This is a form of positive motivation so that there are no extinctions that occur in the Intangible Cultural Heritage, including in the arts, dances and theater. As a Betawi culture that is very close and thick with the presence of major 
influences from China, as well as other cultures, a complete laboratory is needed to study all legalized menus. That is, not just researching but also socializing. Where the existence of Betawi culinary is a belt that connects, strengthens, and strengthens various things and becomes a culture and a community culture.

The same is the case with Akar Kelape. Akar Kelape is a pastry that comes from Betawi. The name of coconut root is taken from its shape which is similar to coconut root. The delicious and sweet taste is an additional attraction of this cake.

This cake is made from white rice flour, coconut, sago flour and other ingredients.

For the Betawi area and its surroundings, this cake is an obligation during Eid.

The cake must come with hotcakes. Besides being served on holidays,

This cake is also served at other celebratory occasions. This cake is generally served with rengginang and fried peanuts during special events, such as during Eid or celebrations.

\subsection{Preparation of Standard Recipes}

\section{Material Ingredient}

$500 \mathrm{~g}$ of glutinous rice flour

$100 \mathrm{~g}$ of corn starch

1 pack of instant coconut milk

2 chicken egg yolks

1 chicken egg white

$200 \mathrm{~g}$ of sugar

1 tablespoon toasted sesame seeds, if desired

125 g margarine

$60 \mathrm{ml}$ of water

The oil for frying

How to make:

- Mix the glutinous rice flour and sago flour, stir until well blended.

- Add coconut milk, eggs, sugar, sesame, and margarine, mix well. Pour in water little by little until the mixture is evenly mixed and smooth

- Enter the dough into the root mold of kelape.

- Heat a lot of oil in a large skillet, spray the mixture directly on the oil until frying immediately.

- Do not use the fire too big so that the coconut roots can dry up to the inside.

- Leave it until brownish yellow, dry and cooked. Remove and drain.

Note: the recipe is for 300 grams 


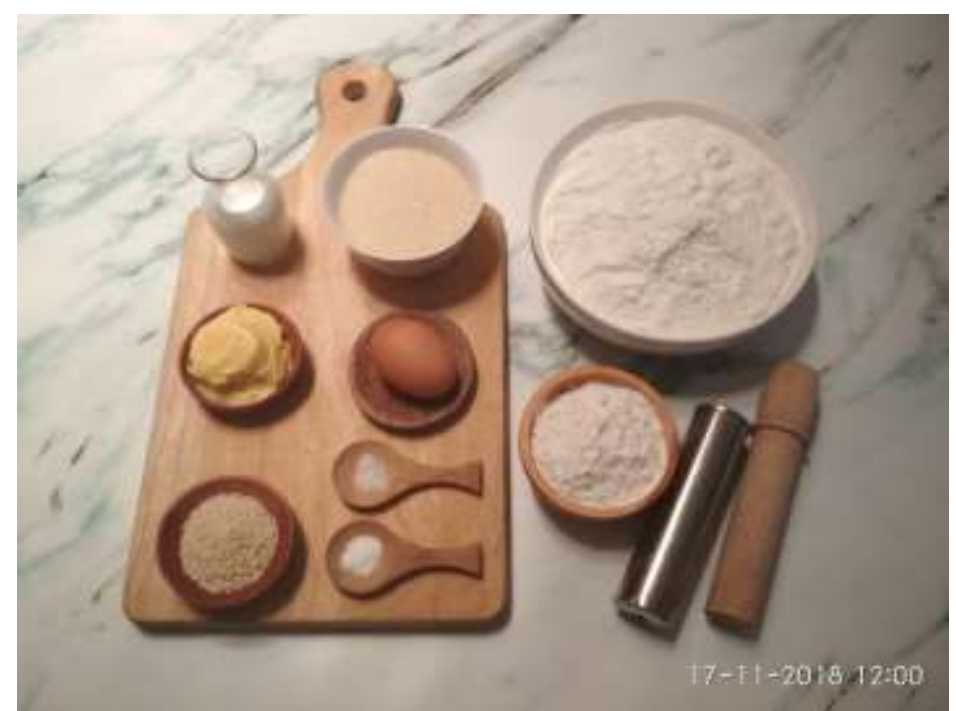

Figure 1. Ingredient Composition of Akar Kelape Source: Primary Data, 2018

\subsection{Serving of Akar Kelape Snack}

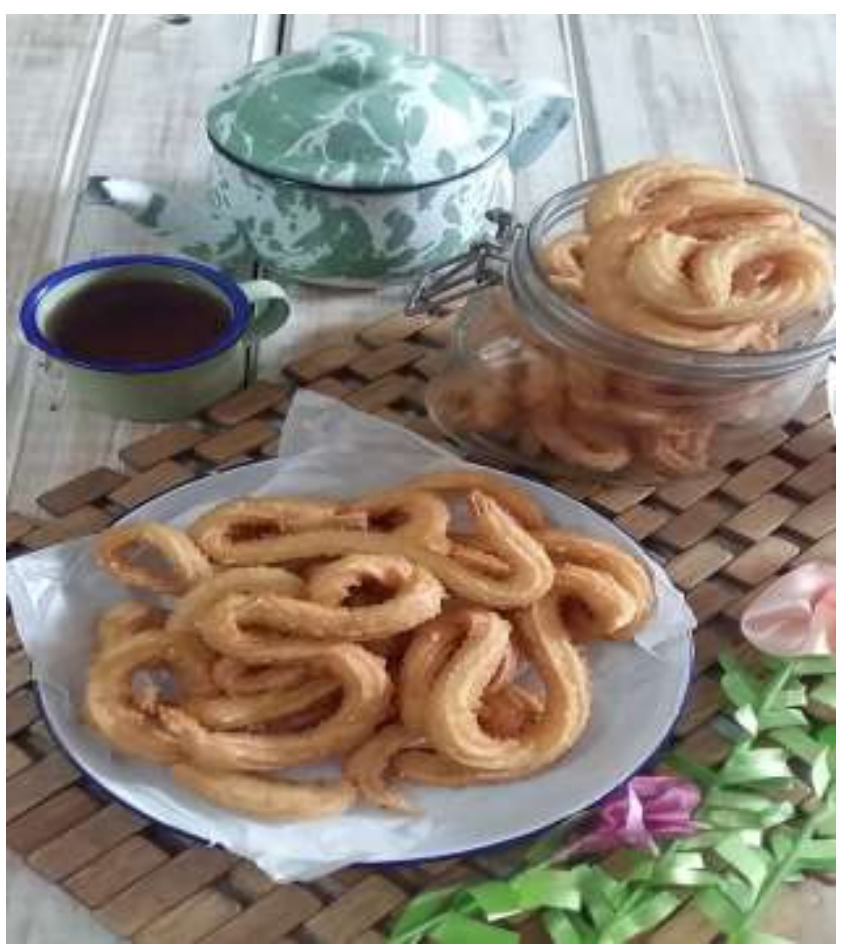

Figure 2. Akar Kelape

Source: Primary Data, 2018 
After the standard Akar Kelape recipe has been prepared, the next step is to create a product that will be of high marketing value. For that, the steps taken are:

1. Creating a brand / brand

2. Make packaging

In this study, based on observations, the brand given to the predetermined standard recipe was Akar Kelape "Nyak Babe", a Betawi Typical Snack with the tagline "Right Treats at the Right Time". While the packaging is made of plastic (vinyl), as seen in the image below

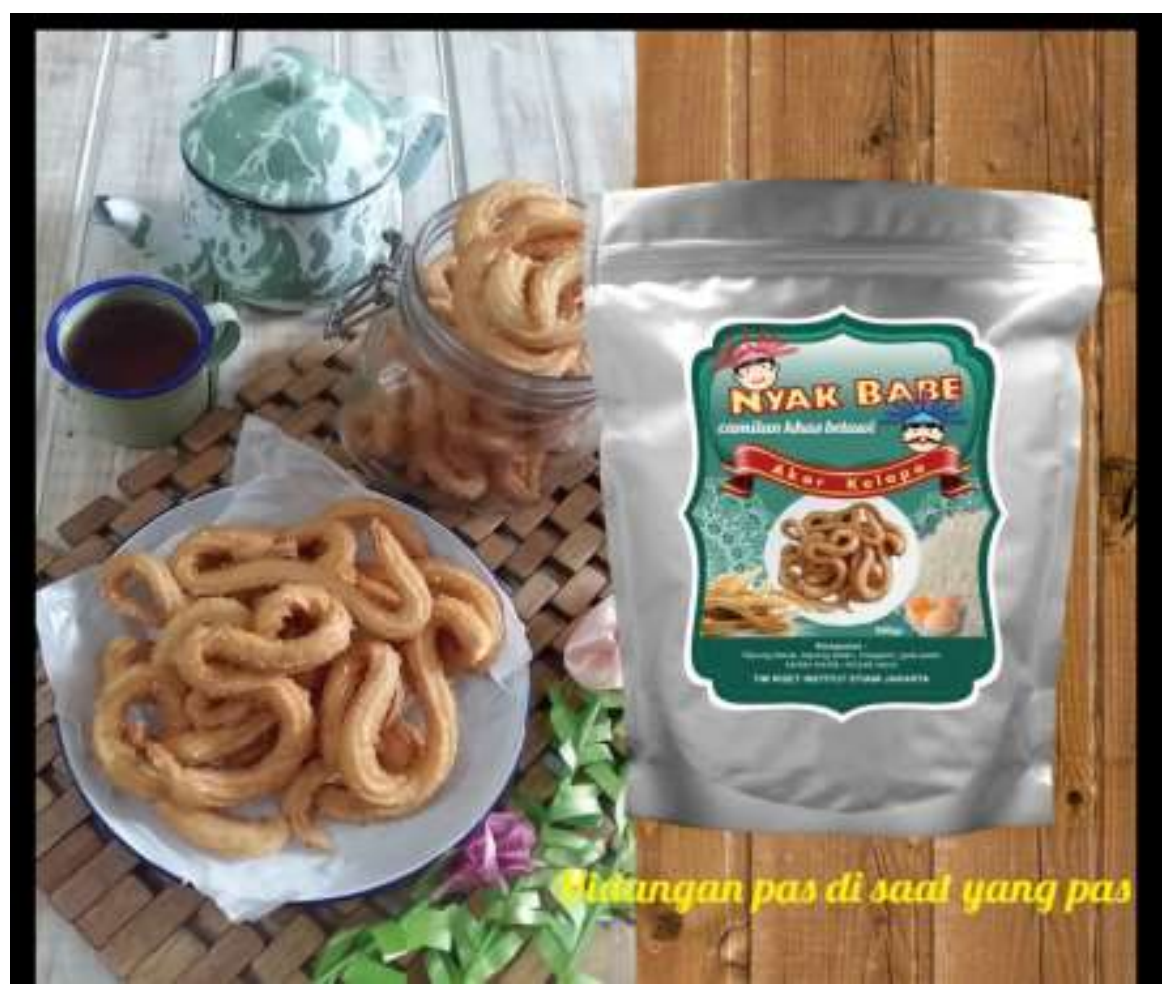

Figure 3 Packing Design of Akar Kelape

Source: Primary Data, 2018

\subsection{Culinary Distribution Area}

The Betawi community consists of three characters:

a. First, the coast which gave rise to maritime culture.

b. Second, it is becoming a populist culture

c. Third, the edge becomes an agricultural culture.

All 10 culinary studies fall into the middle category.

Bekasi is the largest producer of Akar Kelape, but along with the times, this cake is no longer mass produced.. 


\subsection{Culinary Culture Value}

Philosophy

- Betawi cuisine has become a belt that connects, strengthens and strengthens various cultures that are rich in historical values. Like the history of Kali Tirem or Biji Balang.

- Namely there is a Micro Cosmos and a Macro Cosmos which is symbolized by a triangle shape.

- Where there is a complementary connection between obedience to God Almighty. Including the symbol of the earth's alms that consists of pastries and culinary and there are codes to be conveyed.

- Where culinary is another picture of the balance of nature.

- Because culinary cannot be separated from the realm of the mind, namely the values that are transmitted in social life.

- Culinary is born because it cannot be separated from ingredients that are in the surrounding location. In addition, there is also a community creativity.

\subsection{Meaning and Function (Uses)}

There are several Betawi culinary categories that are already rare and are intended for culinary preservation. Among others, Sate Asem, Sengkulun, Sayur Babanci, and Porridge Ase). There are also those that are included in the category of potential development of Betawi souvenirs as souvenirs from tourists who come to DKI Jakarta, especially Betawi villages, namely Ginger Coffee and Coconut Roots. Finally, the culinary delights in the presentation are devoted to Betawi specialties with the aim of being one of the Betawi culinary tours. Among them are Pindang Bandeng, Sate Pentul / Soft, Laksa Betawi, and Selendang Mayang (which are currently being discussed).

In this study, Akar Kelape was researched to be developed into typical Betawi souvenirs as souvenirs, which made it easier for tourists to find Betawi souvenirs, in addition to raising the creativity and economic power of local residents to serve Betawi culinary. In particular, hotels and restaurants in DKI Jakarta Province make Betawi specialties become superior. One way is by making stands in strategic locations to introduce and preserve them for the wider community [3], [4].

\subsection{Culinary Heritage / Maestro / Successor}

Intangible cultural heritage such as this typical Betawi cuisine cannot be separated from the ingredients in the vicinity of DKI Jakarta Province. Then coupled with the creativity of the local community in making these culinary specialties were born. Where the spices or basic ingredients of one culinary with another have differences.

Akar Kelape, it must have differences, for example with similar culinary delights. In essence, human culture and civilization would not exist if there was no food. Because after all, eating and drinking has become a necessity for the community. This is what distinguishes culinary from outside Betawi with different names and ingredients.

\section{Conclusion}

The presentation of Akar Kelape from the standard recipe which is the result of this research, can be used as a guide for culinary preservation, especially traditional Betawi 
cuisine. In this study, based on observations, the brand given to the predetermined standard recipe was Akar Kelape "Nyak Babe", a Betawi Typical Snack with the tagline "Right Treats at the Right Time". To further increase the selling value, a design for the Akar Kelape product packaging has been produced. To further enhance the development of Akar Kelape as a typical Betawi souvenir, it is necessary to formulate a marketing strategy for the Akar Kelape, especially the "Nyak Babe" brand of Akar Kelape, for example promoting through social media, marketing networks, and others.

\section{References}

[1] A. Cavicchi and K. Stancova, Food and gastronomy as elements of regional innovation strategies. 2016.

[2] Inskeep, Edward. 1991. Tourism Planning: An Integrated and sustainable Approach. Van Nostrand Reinhold. New York, Inc.

[3] M. S. J. Sirse, "Gastronomic cities: City strategy on gastronomy as a tool for tourism and emplyment development. Baseline Study,” p. 126, 2014.

[4] Pridia, Heni. 2016. Kuliner Betawi : Selaksa Rasa dan Cerita. Gramedia Pustaka Utama, Jakarta.

[5] T. Sengel, A. Karagoz, G. Cetin, F. I. Dincer, S. M. Ertugral, and M. Balık, "Tourists' Approach to Local Food," Procedia - Soc. Behav. Sci., vol. 195, no. 2013, pp. 429-437, 2015, doi: 10.1016/j.sbspro.2015.06.485.

[6] U. Sormaz, H. Akmese, E. Gunes, and S. Aras, "Gastronomy in Tourism," Procedia Econ. Financ., vol. 39, no. November 2015, pp. 725-730, 2016, doi: 10.1016/S22125671(16)30286-6.

[7] Winarno, F.G. 1993, Makanan Tradisional, Gizi dan Khasiat, Prosiding, Seminar Pengembangan Pangan Tradisional dalam Rangka Penganekaragaman Pangan, Kantor Menteri Negara Urusan Pangan dan Urusan Logistik. 